\title{
Investigating of the effect of entrepreneurial orientations on formation of entrepreneurial identity
}

\author{
Manoochehr Parsian ${ }^{a^{*}}$ and Mohammad Hasan Mobaraki ${ }^{\mathrm{b}}$
}

${ }^{a}$ MSc in Entrepreneurship, Department of Entrepreneurship, University of Tehran, Tehran, Iran ${ }^{b}$ Department of Entrepreneurship, University of Tehran, Tehran, Iran

\section{H R O N I C L E}

Article history:

Received January 5, 2016

Received in revised format August 2, 2016

Accepted August 30, 2016

Available online

August 30, 2016

\section{Keywords:}

Entrepreneurial Identity

Entrepreneurial Orientations

Five Dimensional Model of

Lampkin \& Dess

\begin{abstract}
A B S T R A C T
In today's changing world, success belongs to the communities and organizations that make a significant relationship between scarce resources and capabilities of management and entrepreneurship of their human resource. In other words, societies and the organizations can move forward in the development path that, with creating the necessary conditions, equip their human resources to productive entrepreneurial knowledge and skills to conduct other organizations and community resources to create value and achieve the development, management. Formation of entrepreneurial identity plays an important role for the development of the entrepreneurial spirit in society. In this paper, given the importance of entrepreneurial identity, the role of entrepreneurial orientations based on Lampkin and Dess (1996) [Lumpkin, G. T., \& Dess, G. G. (1996). Clarifying the entrepreneurial orientation construct and linking it to performance. Academy of Management Review, 21(1), 135-172.] is investigated on entrepreneurial identity of the municipality of Qom using a questionnaire consists of 18 items. The results show entrepreneurial orientation influences significantly on entrepreneurial identity.
\end{abstract}

\section{Introduction}

New age is called as a competition area over resources and capitals and major successful industrial countries have increased the productivity of their resources and capitals through applying innovative ideas to reach their objectives. Access to such innovations depends on entrepreneurship activities (Shane \& Venkataraman, 2000; Bauman, 2005). During the past few years, there have been significant efforts on a new form of activities and there is a move towards self-employed activities. Therefore, entrepreneurship and entrepreneurs play key roles in the economic development of communities. The experiences of countries like Japan, South Korea, Malaysia and India were full of cases of entrepreneur's activities, which help development of their countries. It should be noted that entrepreneurs not only create new employment opportunities but also turn to creative development of business activities with structure, thinking, motivation and culture. Entrepreneurship has driven the 
society towards innovative technical change and economic growth and has created new knowledge into new products and services (Hughes, 2006). Given the relative importance of entrepreneurship and its necessity, strengthening the factors that are forming the entrepreneurial spirit is so crucial. Several factors are affecting the entrepreneurial identity including cultural factors (Shilling, 2003, Hughes, 2006), political (Thomas, 2004), economic and entrepreneurial orientations, etc. Entrepreneurial orientations, based on Lampkin and Dess model (1996), has 5 dimensions including risk taking, innovation, leadership, aggressive competition and independence. The impact of entrepreneurial orientation on performance has been studied in several papers (Lumpkin \& Dess, 2001; Barton, 2002; Wiklund \& Shepherd, 2005; Wang, 2008).

In this paper, there is an attempt to review the effects of five entrepreneurial orientations dimensions according to Lampkin and Dess (1996) model on identity formation entrepreneurial. According to Jones (1998) and Jones and Butler (1992) "Entrepreneurship is the process by which firms notice opportunities and act (by creatively organizing transactions between factors of production) to create surplus value".

\section{Literature review}

\subsection{Entrepreneurial identity}

Entrepreneurial identities of cognitive patterns are of behavior copies of interpretations and allow the person to understand what it means to be an entrepreneur. Murnieks et al. (2014) investigated the entrepreneurial identity and defined its characteristics. Entrepreneurial identity is formed when the individual, internalize meanings outer associated with entrepreneurial roles and that meanings become the self-concept. Here the person starts to know himself as entrepreneurial and reflects on the meanings and behaviors associated with entrepreneurial identity. Entrepreneurs have a strong sense of self and tend to know themselves as different from non-entrepreneurs (Murnieks et al., 2014). This indicates that many entrepreneurs could distinguish between the entrepreneurial and other social roles and has deep understanding of the meaning of the relevant roles. For example, many scholars believed of social entrepreneurial identity as Socio-linguistic construct (Down \& Reveley, 2004; Warren, 2004; Watson, 2009).

Anderson and Warren (2011) explored the identity play of one flamboyant entrepreneur, Michael O'Leary, to show how he deployed the rhetoric and rationality of entrepreneurial discourse, but shaped it through emotional games to establish his unique entrepreneurial identity. The study reported strong evidence that entrepreneurs were culturally stereotypical and that this is amplified by the press, but also how O'Leary employed this to engage with the rational and emotional, explaining how this could be used for strategic advantage. Cohen and Musson (2000) analyzed of the enterprise discourse and how it was articulated by individuals working in small business environments, to build material practices and psychological identities.

\subsection{Entrepreneurial orientation}

Lampkin and Dess (1996) examined entrepreneurial orientation and its relationships with the entrepreneurs were measured and evaluated. In this paper, entrepreneurship orientations (EO) were recognized and investigated. They first explained the basic differences and distinctions between entrepreneurship and EO. Similar to Lampkin and Dess's findings, the main action takes place in entrepreneurship is new entry. But the process of entrepreneurial orientations, activities, and making the decisions that lead to new entry were also considered (Lumpkin \& Dess, 1996).

\subsubsection{Dimensions of entrepreneurial orientation}

Lampkin and Dess (1996), based on Miller and Friesen's work (1983), identified and introduced 5 dimensions including Autonomy, Innovativeness, Risk taking, Proactiveness and Aggressiveness. 
Wang (2008) examined the relationship between entrepreneurial orientation, learning orientation and organizational performance. In order to evaluate the entrepreneurship orientations, she pointed out to Lampkin and Dess (1996), Lyon et al. (2000) and Miles and Covin (2002). Li et al (2009) examined the entrepreneurial orientation and organizational performance by examining the impact of the knowledge creation process. Mobaraki et al. (2012) examined the effect of EO on the performance of private insurance companies in Iran.

\subsection{Variables of the research model}

According to the theory outlined in the previous section, variables are defined as follows,

\subsubsection{Independent variable}

According to the Lampkin and Dess model (1996 and 2001), the independent variables are as follows, Innovativeness: Indicates the tendency of a company or person to get involved with new ideas, experimentation, and creative processes that may result in new products, services or business processes and new technologies. In this paper, the impact of innovation, as an entrepreneurial orientation in the formation of entrepreneurial identity, is investigated (Morris \& Kuratko, 2002).

Risk taking: To the extent a company or person engages in risky projects and activities by heavy loans, investing in technologies unexamined, or introducing new products into new markets. Risk-taking, is the core concept of entrepreneurship. They defined an entrepreneur as someone who specializes in responsibility, legal decisions on the location, type and use of goods and affects resources and institutions.

Aggressiveness: To serious challenge and direct with competitors to enter the market or improve the situation in order to surpass competitors in the market or industry. In order to illustrate the impact of aggressive competition on formation of entrepreneurial identity, this variable is also taken into consideration.

Proactiveness: This is mentioned how the company or person brings strategic plans by anticipation and pursues new opportunities which are defined as predictor of future problems and need to change.

Pioneering is another entrepreneurial orientation which influences as an independent variable on the formation of entrepreneurial identity is investigated.

Autonomy: Independent action of an individual or team to forward an idea to accomplish its mission, regardless of organizational boundaries

In the article, autonomy, as the fifth dimension of Lampkin and Dess model, has selected and its impact on identity formation entrepreneurial is reviewed.

\subsubsection{Dependent variable}

In this paper, an entrepreneurial identity and its formation as an independent variable is considered.

Entrepreneurial identity: As mentioned in the theoretical basis, entrepreneurial identities are associated with people the meanings of individual behavior that know them when they are in the role of an entrepreneur entrepreneurial (Murnieks et al., 2014). 


\subsection{Research model}

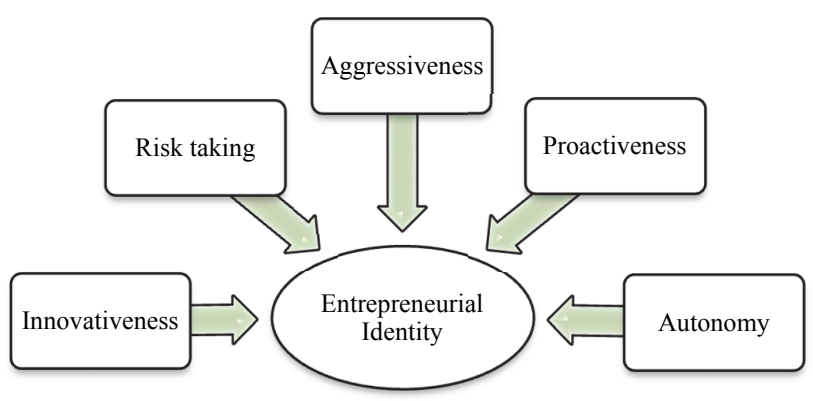

Fig. 1. Research Model

\subsection{Research hypotheses}

Hypotheses examined in this study are as follows,

The main hypothesis: Entrepreneurial orientations has a positive and significant impact on forming entrepreneurial identity in municipality personnel of Qom.

Sub-Hypothesis:

Hypothesis 1: Innovativeness has a positive and significant impact on forming entrepreneurial identity in municipality personnel of Qom.

Hypothesis 2: Risk taking has a positive and significant impact on forming entrepreneurial identity in municipality personnel of Qom.

Hypothesis 3: Aggressiveness has a positive and significant impact on forming entrepreneurial identity in municipality personnel of Qom.

Hypothesis 4: Proactiveness has a positive and significant impact on forming entrepreneurial identity in municipality personnel of Qom.

Hypothesis 5: Autonomy has a positive and significant impact on forming entrepreneurial identity in municipality personnel of Qom.

\section{Research methodology}

The aim of the present study in terms of functional and data collection method is descriptive and survey. Also the way of the analysis is descriptive correlation. In this type, the relationship between the variables is analyzed based on the objectives of the proposed study. In other words, the goal of research is to determine the correlations on changing one or more variables with changing one or more others variables.

\subsection{The statistical population and sample size}

The first step is to determine the statistical population of the study. Population studied in this paper includes employees of the city of Qom, Iran. Given the extent and other limitations of the study population, such as access and time constraints in this study we have attempted to obtain a sample. We have used Cochran formula to determine the sample size.

$$
\mathrm{n}=\frac{\mathrm{Z}^{2}(1-\alpha / 2) \mathrm{pq} \mathrm{N}}{e^{2}(N-1)+\mathrm{Z}^{2}(1-\alpha / 2) \mathrm{pq}}
$$


According to the above formula, the sample size for a community with 480 members and 95 percent confidence is equal to 215 . To answer the research questions and needed data collection, a two-part questionnaire was developed. First the parameters for each variable and then based on these indexes, the questionnaire is devised. The questionnaire is in two parts: A section is on the measurement of entrepreneurial tendencies and the other parts includes the entrepreneurial identity. Then the validity and reliability of questionnaires used are mentioned.

\subsection{Validity and reliability of the survey}

In order to determine the validity, questionnaires were given to professors, advisors and experts in the field in order to provide their comments about being inclusive, taking into consideration all aspects of the subject and the strength of the logical relationship between both these questions and also appropriate questions. Then the corrections were applied where necessary and thus its validity was confirmed by expert standpoint.

To check the reliability, the researcher distributed 40 questionnaires and collected the properly filled ones, action alpha coefficient using SPSS software was used for the questionnaires; the results separately for each variable have been obtained in Table 1 as follows,

Table 1

Reliability test

\begin{tabular}{lc}
\hline Variable & Cronbach's $\alpha$ \\
\hline Entrepreneurial orientations & 0.83 \\
Innovativeness & 0.82 \\
Risk taking & 0.85 \\
Aggressiveness & 0.76 \\
Pro-activeness & 0.81 \\
Autonomy & 0.8 \\
Entrepreneurial identity & 0.84 \\
Total & 0.88 \\
\hline
\end{tabular}

\subsection{Data analysis}

The data was gathered and classified in Excel and after processing they were entered into SPSS software package and the needed analysis was conducted. In order to assess normality, Kolmogorov Smirnov test was used and significant regression and correlation of variables has been obtained. The results are presented in the next section.

\section{Research findings}

\subsection{Normality test data}

Table 2 demonstrates the summary of the results of our survey.

Table 2

Results of Kolmogorov - Smirnov test

\begin{tabular}{lccc}
\hline & Statistics & df & Sig. \\
\hline Entrepreneurial orientations & 0.119 & 215 & 0.058 \\
Innovativeness & 0.124 & 215 & 0.051 \\
Risk taking & 0.013 & 215 & 0.098 \\
Aggressiveness & 0.165 & 215 & 0.139 \\
Proactiveness & 0.087 & 215 & 0.069 \\
Autonomy & 0.114 & 215 & 0.071 \\
Entrepreneurial identity & 0.112 & 215 & 0.088 \\
\hline
\end{tabular}




\subsection{Correlation test}

After determining the normality of the data, Pearson correlation test has been used to assess the relationship among the variables.

Table 3

Correlation between the variables of research hypotheses

\begin{tabular}{lcccc}
\hline Variables & $\begin{array}{c}\text { Number of } \\
\text { Subjects }\end{array}$ & $\begin{array}{c}\text { correlation } \\
\text { coefficient }\end{array}$ & $\begin{array}{c}\text { Sig. } \\
\text { P-value }\end{array}$ & Results \\
\hline Entrepreneurial orientations on Entrepreneurial & 215 & 0.870 & 0.000 & $\mathrm{H}_{0}$ \\
Innovativeness on Entrepreneurial identity & 215 & 0.867 & 0.000 & $\mathrm{H}_{0}$ \\
Risk taking on Entrepreneurial identity & 215 & 0.784 & 0.001 & $\mathrm{H}_{0}$ \\
Aggressiveness on Entrepreneurial identity & 215 & 0.764 & 0.000 & $\mathrm{H}_{0}$ \\
Pro-activeness on Entrepreneurial identity & 215 & 0.819 & 0.000 & $\mathrm{H}_{0}$ \\
Autonomy on Entrepreneurial identity & 215 & 0.795 & 0.000 & $\mathrm{H}_{0}$ \\
\hline
\end{tabular}

\section{Discussion and conclusion}

The results of this study have indicated a significant and positive relationship between entrepreneurial orientation entrepreneurial identities, which means strengthening the entrepreneurial orientation entrepreneurial identity formation process must be accelerated. The results of the five dimensions of Lampkin and Dess (1996) model show that each of these dimensions also affects the formation of entrepreneurial identity. However, their impacts are not the same and influence coefficients obtained for the dimensions are different. This means that entrepreneurial orientations in the municipality among of entrepreneurs must be strengthened. This could happen when additional entrepreneurial identity among staff has been formed and strengthened.

Accordingly, respected managers and administrators must wisely and effectively strengthen the entrepreneurial orientations in their employees.

Innovativeness: A change in workspace-defined tasks and staff makes them come out from lethargic and slow to change and innovation. Staff should not continue to perform routine activities of organizational activities. This causes emotional and intellectual climate of change away. The results show that innovation has the highest association and correlation with entrepreneurial identity. Therefore, we cannot make any improvement without enhancing innovation orientation in people, waiting for entrepreneurial identity in the organization.

Risk-taking: Municipal employees should be allowed to stay within their powers and duties to carry out activities without fear of reprimand or question. We can design this area by human resources professionals for careers. It should also encourage employees to take advantage of opportunities and great successes in the business.

Aggressiveness: Competition between organizations and individuals, when it is a healthy and constructive, can lead to innovative, entrepreneurial environment and growth. However, this healthy competition should not lead to destructive competition in the organization atmosphere. When people understand the organization's incentives and promotions, the spirit of competitiveness among them is strengthened. Regulatory and payment systems based on the activities and achievements of individuals must be considered. The organization must pay to vote and administrator must differentiate between these scores and scores of warriors in organization. Organization and management's focus on customer satisfaction and manner activity could also be another factor in strengthen aggressive competitive in among staff. 
Pro-activeness: The organization must allow employees to succeed and grow, try new ways of managing organization. For example, employees can adopt modern methods for customer satisfaction. These methods are based on employees' creativity and innovation, which could make a difference. Also organization in case of useful people inventive method can be introduced in these methods in the organization and thereby increase the competitiveness of the organization.

Autonomy: The organization should have plans to identify creative and empowering their employees through seminars and training courses and faculty traveling to conferences. Thus the skills levels of people can be greatly increased. Also, entrusting creative staff and encouraging them to think outside the corporate limits can be fruitful.

\section{Acknowledgement}

The authors would like to thank the anonymous referees for constructive comments on earlier version of this paper.

\section{References}

Anderson, A. R., \& Warren, L. (2011). The entrepreneur as hero and jester: Enacting the entrepreneurial discourse. International Small Business Journal,29(6), 589-609.

Bauman, Z. (2005). Identity for Identity's Sake is a Bit Dodgy.... Soundings,29(1), 12-20.

Cohen, L., \& Musson, G. (2000). Entrepreneurial identities: reflections from two case studies. Organization, 7(1), 31-48.

Down, S. (2006). Narratives of enterprise: Crafting entrepreneurial self-identity in a small firm. Edward Elgar Publishing.

Down, S., \& Reveley, J. (2004). Generational encounters and the social formation of entrepreneurial identity:'young guns' and 'old farts'.Organization, 11(2), 233-250.

Barton, L., Barnes, C., \& Oliver, M. (2002). Disability studies today. Polity Press.

Hughes, K. D. (2006). Exploring motivation and success among Canadian women entrepreneurs. Journal of Small Business \& Entrepreneurship, 19(2), 107-120.

Jones, G. R., \& Butler, J. E. (1992). Managing internal corporate entrepreneurship: An agency theory perspective. Journal of Management,18(4), 733-749.

Jones, R., Latham, J., \& Betta, M. (2008). Narrative construction of the social entrepreneurial identity. International Journal of Entrepreneurial Behavior \& Research, 14(5), 330-345.

Li, Y. H., Huang, J. W., \& Tsai, M. T. (2009). Entrepreneurial orientation and firm performance: The role of knowledge creation process. Industrial marketing management, 38(4), 440-449.

Lumpkin, G. T., \& Dess, G. G. (1996). Clarifying the entrepreneurial orientation construct and linking it to performance. Academy of management Review, 21(1), 135-172.

Lumpkin, G. T., \& Dess, G. G. (2001). Linking two dimensions of entrepreneurial orientation to firm performance: The moderating role of environment and industry life cycle. Journal of business venturing, 16(5), 429-451.

Lyon, D. W., Lumpkin, G. T., \& Dess, G. G. (2000). Enhancing entrepreneurial orientation research: Operationalizing and measuring a key strategic decision making process. Journal of management, 26(5), 1055-1085.

Miles, M. P., \& Covin, J. G. (2002). Exploring the practice of corporate venturing: Some common forms and their organizational implications.Entrepreneurship: Theory and Practice, 26(3), 21-41.

Miller, D., \& Friesen, P. H. (1983). Strategy-making and environment: the third link. Strategic management journal, 4(3), 221-235.

Mobaraki, M.H., Zali, M.R., Abdolvahab, S., \& Moghimi Esfandabadi, H. (2012) Studying the effects of entrepreneurial orientations on performance based on Lumpkin and Dess model in private insurance companies in Iran. Journal of Insurance Research, 27(3), 71-95. 
Morris, M. H., \& Kuratko, D. F. (2002). Corporate entrepreneurship: Entrepreneurial development within organizations. South-Western Pub.

Murnieks, C. Y., Mosakowski, E., \& Cardon, M. S. (2014). Pathways of passion identity centrality, passion, and behavior among entrepreneurs.Journal of Management, 40(6), 1583-1606.

Oliver, M. (1996). Defining impairment and disability: issues at stake.Exploring the divide: Illness and disability, 39-54.

Shane, S., \& Venkataraman, S. (2000). The promise of entrepreneurship as a field of research. Academy of management review, 25(1), 217-226.

Shilling, C. (2003). The Body and Social Theory. $2^{\text {nd }}$ ed., London: Sage.

Thomas, C. (2004). Disability and impairment. J. Swain et al., Hrsg, 2, 21-27.

Wang, C. L. (2008). Entrepreneurial orientation, learning orientation, and firm performance. Entrepreneurship theory and practice, 32(4), 635-657.

Warren, L. (2004). Negotiating entrepreneurial identity-Communities of practice and changing discourses. The International Journal of Entrepreneurship and Innovation, 5(1), 25-35.

Watson, T. J. (2009). Entrepreneurial action, identity work and the use of multiple discursive resources the case of a rapidly changing family business.International Small Business Journal, 27(3), 251274.

Wiklund, J., \& Shepherd, D. (2005). Entrepreneurial orientation and small business performance: a configurational approach. Journal of business venturing, 20(1), 71-91.

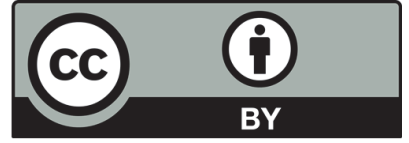

(C) 2016 by the authors; licensee Growing Science, Canada. This is an open access article distributed under the terms and conditions of the Creative Commons Attribution (CC-BY) license (http://creativecommons.org/licenses/by/4.0/). 